\title{
ISOLATION AND IDENTIFICATION OF THE BACTERIAL COMMUNITY ASSOCIATED WITH THE ROVE BEETLE, Paederus fuscipes CURTIS (COLEOPTERA: STAPHYLINIDAE) IN PENANG
}

\author{
SUFIAN MARYAM ${ }^{1}$, ABDULLAH AL-ASHRAF AMIRUL $^{1}$ and WAN FATMA ZUHARAH ${ }^{1,2^{*}}$ \\ ${ }^{I}$ School of Biological Sciences, Universiti Sains Malaysia, 11800 Minden, Penang, Malaysia \\ ${ }^{2}$ Vector Control Research Unit, School of Biological Sciences, Universiti Sains Malaysia, \\ 11800 Minden, Penang, Malaysia \\ *E-mail: wanfatma@gmail.com
}

Accepted 12 June 2020, Published online 30 June 2020

\begin{abstract}
The rove beetle, Paederus fuscipes Curtis has caused tremendous dermatitis once unintentionally crushed against human skin due to their potent toxic released called paederin produce by the endosymbiont bacteria. The genus Pseudomonas was hypothesized to be the endosymbiont bacteria involved in the production of paederin in Paederus. However, no extensive studies have been performed to investigate the existence of other bacteria, and the relationship between the endosymbiont counts amongst male and female $P$. fuscipes beetles. We found that $P$. fuscipes harbours surprising numbers of bacteria diversity with a total of 20 different bacterial species identified. Bacillus, Serratia, Staphylococcus, and Pseudomonas bacteria were the dominated genus found in all collected beetles from all light trap locations. However, only Pseudomonas aeruginosa Migula is the medically important species and is commonly known to cause severe dermatitis lesions to humans. Our results revealed the $P$. aeruginosa counts cultured on Pseudomonas medium was found higher total mean bacteria counts in $P$. fuscipes females $\left(2.58 \times 10^{5} \pm 2.73 \times 10^{4}\right.$ cell $)$ compared to male beetles $\left(5.68 \times 10^{4} \pm 3.70 \times 10^{3}\right.$ cells $)$. We demonstrated that a large diversity of bacterial community has been isolated from both male and female $P$. fuscipes, however $P$. aeruginosa colonies were frequently detected in females compared to male beetles. These results can be used in future studies to investigate the possible impact of these bacterial counts on the concentration of paederin produced in P. fuscipes.
\end{abstract}

Key words: Endosymbionts, Paederus, Paederus fuscipes. Pseudomonas, 16srRNA gene

\section{INTRODUCTION}

The family Staphylinidae includes some of the world's most significant insect species that can cause important clinical manifestations via vesicant toxin to their victims (Haddad et al., 2012). Although mosquitoes, tsetse flies, and sand flies are mainly recognized as the vectors of tropical diseases associated with mortality, the rove beetle of the genus Paederus is also a threat to mankind, due to the toxic hemolymph paederin (Ghoneim, 2013). Paederin is an extremely potent vesicant polyketide cytotoxin that causes paederus dermatitis (also known as dermatitis linearis) skin lesion once unintentionally crushed against human skin (Piel, 2002; Gibbs, 2015). Severe dermatologic, ophthalmologic, and systemic symptoms are shown

\footnotetext{
* To whom correspondence should be addressed.
}

by a paederus dermatitis victim (Cressey et al., 2013). The first reported case of paederus dermatitis was in the summer back to the late nineteenth century at Anjet-Kidoel lighthouse in Java, Indonesia (Vorderman, 1901). Since then, it has become a nuisance pest due to its significant public health problems to humans (Bong et al., 2015).

Nonetheless, the benefits provided by paederin for Paederus beetles are contradicted with the problems caused to human beings. In tropical regions of Asia, massive outbreak cases were frequently reported in human-dominated areas because these insects live exclusively on moist environmental conditions such as near river margins, lakes, and rice field areas which are built close to human residential premises (Bong et al., 2015). Bright illumination is one of the factors in causing Paederus beetle infestation into human settings 
(Maryam et al., 2017b). Interestingly, most incidences of infestation were mostly observed in the northern region of Peninsular Malaysia (Bong et al., 2013).

Remarkably, it was indicated that paederin is not produced by the beetle themselves but relies on some species of an endosymbiont bacteria within the Paederus spp. which is known to be phylogenetically related to Pseudomonas aeruginosa (Kellner, 2002). The capability to synthesize paederin is limited to only certain female adults, whereas the males and larvae can acquire the toxin only by ingestion or transovarially (Kellner \& Dettner, 1995). According to Dillon and Dillon (2004), bacterial association with insects affects their hosts in various ways from making a nutritional contribution, aids food digestion, reproduction and protection against pathogenic colonization. For instance, paederin plays an important role in protecting Paederus larvae through the chemical defense to survive the attacks against predation by wolf spiders (Kellner \& Dettner, 1996). In this study, we isolated, cultured, and identified the symbiont bacteria from $P$. fuscipes to obtain a more precise estimation of their occurrence in both male and female beetles.

\section{MATERIALS AND METHODS}

\section{Sampling site and Paederus fuscipes samples}

Paederus fuscipes specimens were collected from Telok Air Tawar rice fields (N $5^{\circ} 29^{\prime} 9.3171^{\prime \prime}$ E $\left.100^{\circ} 23^{\prime} 1.3012^{\prime \prime}\right)$ in mainland Penang, Malaysia. CDC Fay-Prince suction light trap baited with a $4 \mathrm{~W}$ blacklight UV bulb hereafter called the "UV light trap" was used as a visual cue to capture $P$. fuscipes beetles in the field. Each UV light trap (named as LT 1, LT 2, LT 3, and LT 4) was deployed on every four sides of the square experimental rice field plots measuring $100 \mathrm{~m}$ in height by $130 \mathrm{~m}$ in width. LT 1 and LT 3 are located closer to human housing premises, whereas LT 2 and LT 4 are more to the center of the rice field areas. All of the UV light traps were operated at the same time from dusk, and insect trapping was conducted over a $2 \mathrm{~h}$ period from 2015 to $2215 \mathrm{~h}$. A specific time was selected due to the peak time of $P$. fuscipes dispersal flight (Maryam et al., 2017a). Captured individuals placed in labeled collection jar, brought back to the Medical Entomology Laboratory, Universiti Sains Malaysia, and beetles were sexed apart. Two adult beetles (one of each sex) from each different UV light trap were tested for the isolation of bacteria. Sampling collection was replicated three times $(n=3)$ on different occasions.

\section{Isolation and enumeration of bacteria}

A day prior to the experiment, P. fuscipes beetles were captured and were then killed using $70 \%$ chloroform. Beetles were individually placed in a sterile $1.5 \mathrm{~mL}$ microcentrifuge tube, washed in a series of three baths containing sterile distilled water, $70 \%$ ethanol, and vortexed (approx. 1 to 2 $\min$ ), and then rewashed again using sterile distilled water. Using standard aseptic techniques, sterilized beetles were then transferred into a new $1.5 \mathrm{~mL}$ microcentrifuge tube containing $200 \mu \mathrm{L}$ of sterile saline $(0.85 \% \mathrm{NaCI})$, individually mashed using a sterile forcep, and was briefly vortexed. The microcentrifuge tube was then centrifuged, to separate the debris from the mashed beetles. All necessary material for handling $P$. fuscipes beetle was autoclaved at $121^{\circ} \mathrm{C}$ for $20 \mathrm{~min}$ prior to the experiment.

In order to assess the distribution and population levels of bacterial communities in a Paederus beetle, an aliquot of $100 \mu \mathrm{L}$ of each extract samples was then transferred to several bijou bottles with a concentration of $10^{-1}, 10^{-2}$ and $10^{-3}$ respectively. The bijou bottles were then vortexed for $1 \mathrm{~min}$ to ensure a homogeneous suspension of bacterial cells. Finally, $100 \mu \mathrm{L}$ of each homogenized serial dilutions were directly plated on two selected microbiological media, (1) Nutrient Agar (NA), and (2) Pseudomonas Agar Base with the addition of CFC supplement for the selective isolation of Pseudomonas species. Firstly we ran the bacterial identification on NA in order to understand the range and amount of different species of bacterial communities found in $P$. fuscipes beetle. On the second batch of the experiment, Pseudomonas agar base with added CFC supplement was used to identify and confirm all possible Pseudomonas bacteria found in both male and female $P$. fuscipes beetles. Different $P$. fuscipes individuals were used for each experimental design. All of the media were prepared according to the manufacturers' instructions (HIMEDIA). The spread plate method was run on triplicates for each concentration. Plates were incubated at $37^{\circ} \mathrm{C}$ for $24 \mathrm{~h}$. Microbial enumeration was done in triplicates by counting the colony-forming units (CFU) per beetle.

\section{Colony characteristics of isolates}

Microorganisms were first screened based on (a) colony characteristics (pigmentation, size, shape, opacity, margin, elevation, viscosity, surface texture) and (b) Gram's staining of the isolates for Gram-positive and Gram-negative identification was conducted by following a standardized Gram staining procedure by Claus (1992). Morphologically distinct and well-isolated 
colonies were aseptically picked by using a sterile inoculation loop, restreaked onto new media plates and subcultured twice to ensure the purity or until pure colonies were obtained. A representative of each colony type was then selected from each sample for sequencing. Isolate names were labeled as follows; (1) R1, R2, and R3 represent the number of sampling replicates, (2) $\mathrm{M}$ and $\mathrm{F}$ represent male and female beetles, and (3) 1, 2, 3, and 4 represents the location of the UV light traps.

\section{Genomic DNA extraction}

A single pure colony of $24 \mathrm{~h}$ culture of the different isolated bacterium on each media was inoculated in $50 \mathrm{~mL}$ of sterile nutrient-rich (NR) broth in separate $250 \mathrm{~mL}$ flask and incubated overnight at $30^{\circ} \mathrm{C}$ with the agitation of $200 \mathrm{rpm}$ in a shaking incubator. After $24 \mathrm{~h}$, a total amount of $1 \mathrm{~mL}$ cultured bacteria cells was then transferred to a $1.5 \mathrm{~mL}$ sterile microcentrifuge tube. The cultures were centrifuged at $15,000 \times \mathrm{g}$ for $1 \mathrm{~min}$, and the supernatant was discarded. DNA extraction was performed using a HiYield Genomic DNA Mini Extraction Kit (RBC, Taiwan) according to the manufacturer's instructions with some modification on the wash step and DNA elution. Briefly, following the cell lysis, DNA binding and wash step, $100 \mu \mathrm{L}$ of pre-heated Elution buffer was added to the dried GD Column which was previously centrifuged for additional 5 min during the wash step to avoid any residual ethanol carryover and was finally let to stand for at least 5 min for complete absorption of the elution buffer. To elute the purified DNA, centrifugation at $15,000 \times \mathrm{g}$ for $30 \mathrm{sec}$ was done, and the genomic DNA was stored at $-20^{\circ} \mathrm{C}$ until further analysis.

\section{Polymerase chain reaction (PCR)}

The 16S rRNA gene was amplified from bacterial colonies by PCR, using universal primer pairs $60 \mathrm{~F}$ (TNANACATGCAAGTCGAAKCG) and 1392 R (ACGGGCGGTGTGTRC) (My TACG Bioscience Enterprise, Selangor, Malaysia). The PCR reaction mixture $(25 \mu \mathrm{L})$ was performed by adding $1 \mu \mathrm{L}$ of template DNA, $0.25 \mu \mathrm{L}$ of each forward and reverse primers, and $11.0 \mu \mathrm{L}$ of nuclease-free water to $12.5 \mu \mathrm{L}$ of EconoTaq PLUS GREEN 2X Master Mix (Lucigen, USA). The $25 \mu \mathrm{L}$ PCR reaction mixture was transferred individually into a clean $0.2 \mathrm{~mL}$ PCR tubes.

Before the PCR was performed in a PCR thermocycler (MyCycler, Bio-Rad, USA), each reaction mixture was mixed gently by vortexing and a brief spin. Cycling parameters for PCR reactions were carried out according to the following protocol: an initial denaturation step at $94^{\circ} \mathrm{C}$ for $2 \mathrm{~min}$, followed by 30 cycles of a denaturation step at $94^{\circ} \mathrm{C}$ for $30 \mathrm{sec}$, a primer annealing step at $54^{\circ} \mathrm{C}$ for $30 \mathrm{sec}$, an extension step at $72^{\circ} \mathrm{C}$ for 1 min, and a final extension step of $10 \mathrm{~min}$ at $72^{\circ} \mathrm{C}$. All PCR products were then subjected to gel electrophoresis.

\section{Agarose gel electrophoresis}

Agarose gel electrophoresis was performed as described by Sambrook and Russell (2001) to separate and identify DNA fragments after DNA extraction and PCR procedure. Aliquots of $6 \mu \mathrm{L}(1: 5$ ratios of $6 \mathrm{X}$ Bromophenol Blue and Xylene Cyanol loading dye to DNA samples) of each product were resolved electrophoretically on $0.8 \%(\mathrm{w} / \mathrm{v})$ agarose gel using $0.5 \mathrm{x}$ TBE buffer stained with $3 \mu \mathrm{L}$ of Health View nucleic acid. The gel electrophoresis was run for $70 \mathrm{~V}$ for $40 \mathrm{~min}$ and was then visualized under UV transilluminator. The DNA molecular weight marker, a $1 \mathrm{~kb}$ DNA ladder (Lucigen, USA) was used to determine the size of the DNA fragments. Once a single band was observed on an agarose gel, the non-purified PCR product was sent to Genomics Bioscience and Technology Laboratory, Taiwan for DNA sequencing. The obtained DNA sequences were assembled through manual alignment using BioEdit software (Hall, 1999). The aligned sequences were then analyzed using the standard nucleotide Basic Local Alignment Search Tool (BLAST) server at the National Center for Biotechnology Information (NCBI) https://blast. ncbi.nlm.nih.gov/Blast.cgi.

\section{Data analysis}

An independent t-test was performed to determine any significant difference in the CFU counts of bacteria isolated from both male and female $P$. fuscipes. Prior to statistical analyses, all data were checked for normality of distribution at the 0.05 significance level by using the ShapiroWilk Normality test. Data were log-transformed prior to analysis. All analyses were conducted using SPSS version 20.0 (SPSS Inc., Chicago, IL, USA).

\section{RESULTS}

Characterisation of bacteria isolated from $P$. fuscipes, cultured on nutrient agar (NA)

\section{Bacterial count on nutrient agar}

In general, the total bacterial counts on the NA for female $P$. fuscipes were found lower as compared to the male $P$. fuscipes beetles after a $24 \mathrm{~h}$ incubation period with mean values of $5.15 \times 10^{5} \pm$ $8.23 \times 10^{4}$ and $2.19 \times 10^{6} \pm 2.70 \times 10^{5}$ respectively. T-test analysis showed no significant difference $(\mathrm{t}=1.52 ; \mathrm{df}=19 ; \mathrm{P}=0.145)$ of the mean number of viable bacteria colonies among male and female $P$. fuscipes beetles on NA. The highest mean number 
of viable bacterial count of female beetles with 1.18 $\mathrm{x} 10^{6} \pm 7.75 \times 10^{4}$ was collected from LT 3 , whereas LT 4 possessed the lowest mean number of viable bacterial counts with $1.64 \times 10^{5} \pm 7.75 \times 10^{4}$ (Table 1). However, at LT 1 , the number of viable bacterial cells was TFTC in all female beetles throughout the three sampling occasions. In contrast, male beetles collected from LT 4 showed the lowest mean number of viable bacterial counts with $2.26 \times 10^{5} \pm 2.96 \times 10^{4}$ of bacterial cells and the highest mean number of bacterial count of male beetles was with $6.31 \times 10^{6} \pm 7.27 \times 10^{5}$ bacterial cells collected from LT 2 (Table 1).

\section{Characteristics of the isolates on nutrient agar}

On the nutrient agar, a total of 15 different isolates were selected and cultured from different individuals of $P$. fuscipes beetle (Table 2). Gramnegative rods were the major group of bacteria found in P. fuscipes individuals, represented by 7 isolates (out of 15). Many of the Gram-negative rods bacteria were found in LT 1 and LT 4 throughout the sampling period in both male and female beetles. Four isolates of each Gram-positive rods and coccishaped bacteria were also identified in all four light traps. However, the number of cocci-shaped bacteria found in male beetles (R2M3, R3M3, and R3M4) was higher compared to female beetles (R3F1). Based on the morphological characteristics, an estimation of 15 different species of bacteria is found in $P$. fuscipes.

\section{Molecular identification of the bacterial isolates on nutrient agar}

Fifteen species of bacteria were identified from nine different genera isolated from $P$. fuscipes at different light trap locations on NA. Isolates were

Table 1. The mean number of viable bacterial cells of $P$. fuscipes individual on nutrient agar (NA)

\begin{tabular}{lcc}
\hline & $\begin{array}{c}\text { Paederus } \\
\text { beetles }\end{array}$ & CFU per beetle \\
\hline Light trap 1 & $\begin{array}{c}\text { Female } \\
\text { Male }\end{array}$ & $\begin{array}{c}\text { TFTC } \\
\text { Light trap 2 }\end{array}$ \\
& Female & $7.17 \times 10^{6} \pm 1.74 \times 10^{5}$ \\
Light trap 3 & Male & $6.31 \times 10^{6} \pm 7.27 \times 10^{5}$ \\
& Female & $1.18 \times 10^{6} \pm 7.75 \times 10^{4}$ \\
Light trap 4 & Male & $8.72 \times 10^{5} \pm 1.48 \times 10^{5}$ \\
& Female & $1.64 \times 10^{5} \pm 7.75 \times 10^{4}$ \\
& Male & $2.26 \times 10^{5} \pm 2.96 \times 10^{4}$ \\
\hline
\end{tabular}

TFTC indicates too few too count.

Table 2. Characteristics of isolated bacteria from $P$. fuscipes beetle, cultured on nutrient agar (NA) at different collection points

\begin{tabular}{|c|c|c|c|c|c|c|c|c|c|}
\hline \multirow{2}{*}{ Isolate } & \multicolumn{8}{|c|}{ Colony Morphology } & \multirow{2}{*}{$\begin{array}{c}\text { Gram's } \\
\text { Stain }\end{array}$} \\
\hline & Pigmentation & Size & Shape & Opacity & Margin & Elevation & Viscosity & $\begin{array}{l}\text { Surface } \\
\text { texture }\end{array}$ & \\
\hline R1F2 & White & Medium & Circular & Opaque & Entire & Convex & Yes & Glistening & Rod, -ve \\
\hline R1F4 & Dark orange & Small & Circular & Opaque & Entire & Flat & Yes & Glistening & Rod, -ve \\
\hline $\mathrm{R} 1 \mathrm{M} 1$ & Yellow & Small & Circular & Opaque & Entire & Flat & Yes & Smooth & Rod, +ve \\
\hline R1M4 & Fair white & Medium & Circular & Opaque & Entire & Convex & Yes & Smooth & Rod, -ve \\
\hline $\mathrm{R} 2 \mathrm{~F} 1$ & Fair white & Medium & Circular & Translucent & Entire & Flat & No & Rough & Rod, +ve \\
\hline $\mathrm{R} 2 \mathrm{~F} 4$ & White & Large & Circular & Opaque & Entire & Raised & Yes & Dull & Rod, +ve \\
\hline $\mathrm{R} 2 \mathrm{~F} 4$ & Yellowish & Medium & Circular & Opaque & Entire & Raised & Yes & Smooth & Rod, -ve \\
\hline R2M1 & $\begin{array}{l}\text { Slightly } \\
\text { yellowish }\end{array}$ & Medium & Circular & Opaque & Entire & Flat & Yes & Smooth & Rod, -ve \\
\hline R2M3 & Clear white & Small & Circular & Transparent & Entire & Convex & Yes & Glistening & $\begin{array}{l}\text { Coccus, } \\
+ \text { ve }\end{array}$ \\
\hline R2M4 & $\begin{array}{l}\text { Fair white- } \\
\text { yellowish }\end{array}$ & Medium & Circular & Translucent & Entire & Flat & Yes & Smooth & Rod, -ve \\
\hline $\mathrm{R} 3 \mathrm{~F} 1$ & Greenish & Large & Circular & Translucent & Entire & $\begin{array}{l}\text { Grow in } \\
\text { medium }\end{array}$ & Yes & Glistening & Rod, -ve \\
\hline $\mathrm{R} 3 \mathrm{~F} 1$ & $\begin{array}{l}\text { Orange- } \\
\text { yellow }\end{array}$ & Medium & Irregular & Opaque & Undulate & Flat & No & Rough & $\begin{array}{l}\text { Coccus, } \\
+ \text { ve }\end{array}$ \\
\hline R3F4 & $\begin{array}{l}\text { Creamy- } \\
\text { white }\end{array}$ & Large & $\begin{array}{l}\text { Filamentous/ } \\
\text { irregular }\end{array}$ & Opaque & Filamentous & Flat & Yes & Rough & Rod, +ve \\
\hline R3M3 & $\begin{array}{l}\text { Creamy- } \\
\text { orange }\end{array}$ & Medium & Circular & Opaque & Entire & Flat & Yes & Glistening & $\begin{array}{l}\text { Coccus, } \\
+ \text { ve }\end{array}$ \\
\hline R3M4 & $\begin{array}{l}\text { Fluorescent- } \\
\text { yellow }\end{array}$ & Small & Circular & Opaque & Entire & Convex & Yes & Glistening & $\begin{array}{l}\text { Coccus, } \\
+ \text { +ve }\end{array}$ \\
\hline
\end{tabular}


subjected to $16 \mathrm{~S}$ rRNA gene sequence analysis and the following bacterial genera were identified as Serratia, Chryseobacterium, Microbacterium, Pseudomonas, Paenibacillus, Bacillus, Stapylococcus, Acinetobacter, and Micrococcus (Table 3). Bacillus, Serratia, Staphylococcus, and Pseudomonas bacteria were identified most commonly in all light trap locations in both male and female beetles based on the number of bacterial colonies grown on the NA media. Nonetheless, bacterial species of the genus Staphylococcus were commonly found in male beetles (R2M3, R3M3) compared to females (R3F1).

However, $P$. aeruginosa colony was only identified on a female beetle from LT 1 location. This bacterium exhibits a slimy texture of green pigments on NA. Nevertheless, other Pseudomonas species; Pseudomonas nitritireducens Lizula and Komagata, Pseudomonas mosselii Dabboussi, and $P$. taiwanensis Wang were also identified in both female and male beetles and were obtained from 10 out of 24 individuals sampled from LT 1, LT 2, LT 3, and LT 4 location.

Characterisation of bacteria isolated from $\boldsymbol{P}$. fuscipes, cultured on Pseudomonas agar

\section{Bacterial count on Pseudomonas agar}

To confirm the existence of different Pseudomonas species found, the selective Pseudomonas medium was used to inoculate and culture bacteria. The total mean number of viable bacterial counts on males was found generally lower as compared to females on the selective Pseudomonas agar with $8.59 \times 10^{5} \pm 1.29 \times 10^{5}$ and $1.32 \times 10^{6} \pm 3.92 \times 10^{5}$ bacterial cells respectively. At LT 2, the lowest mean number of the bacterial count with $2.70 \times 10^{5} \pm 5.08 \times 10^{4}$ bacterial cells were observed on male beetle, while the highest CFU counts in males were found at LT 3 with 2.70 x $10^{6} \pm 4.48 \times 10^{5}$ bacterial cells. Whereas, females accounted for the highest mean number of viable bacterial count of $4.00 \times 10^{6} \pm 1.45 \times 10^{6}$ bacterial cells at LT 3 location, and the lowest in females was with $4.85 \times 10^{5} \pm 5.06 \times 10^{4}$ bacterial cells at LT 4 .

Conversely, the specific green coloured pigment produced from $P$. aeruginosa species was found collected from $P$. fuscipes female at LT 1 with the highest mean number of CFU counts of $7.75 \times 10^{5}$ $\pm 7.08 \times 10^{4}$. While, the least mean number of $P$. aeruginosa counts on male beetle was from LT 4 with $2.27 \times 10^{5} \pm 1.48 \times 10^{4}$ bacterial cells. Overall, numerous $P$. aeruginosa colonies were found from three $P$. fuscipes females compared to only two male beetles, however, this difference was not significant $(\mathrm{t}=1.69 ; \mathrm{df}=14 ; \mathrm{P}=0.113$; Table 4).

\section{Characteristics of the isolates on Pseudomonas agar}

A total of six different bacterial isolates were cultured from $P$. fuscipes on the selective Pseudomonas agar from all light trap locations. All isolates were Gram-negative rod-shaped bacteria which indicates the possibility of $P$. aeruginosa species. The colony and cell morphologies based on Gram's staining of the bacteria on Pseudomonas agar were summarized in Table 5 with an estimation of a possibility of six identified Pseudomonas species.

\section{Molecular identification of the bacterial isolates on Pseudomonas agar}

Three out of six identified species were found to be among the Pseudomonas species. Besides $P$. aeruginosa, Pseudomonas oryzihabitans Kodoma, and Pseudomonas entomophila were the identified

Table 3. The 16S rRNA gene sequence of isolated bacteria from $P$. fuscipes on nutrient agar (NA)

\begin{tabular}{|c|c|c|c|c|c|}
\hline Isolate & Bacteria & $\begin{array}{c}\text { Maximum } \\
\text { Identity (\%) }\end{array}$ & $\begin{array}{c}\text { Query } \\
\text { Coverage (\%) }\end{array}$ & E value & $\begin{array}{c}\text { Accession } \\
\text { Number }\end{array}$ \\
\hline R1F2 & Serratia nematodiphila & 99 & 100 & 0.0 & MK 163508 \\
\hline $\mathrm{R} 1 \mathrm{~F} 4$ & Chryseobacterium vietnamense & 98 & 100 & 0.0 & MK 163509 \\
\hline $\mathrm{R} 1 \mathrm{M} 1$ & Microbacterium paraoxydans & 99 & 100 & 0.0 & MK 163510 \\
\hline R1M4 & Pseudomonas nitritireducens & 97 & 100 & 0.0 & MK 163511 \\
\hline $\mathrm{R} 2 \mathrm{~F} 1$ & Paenibacillus glycanilyticus & 94 & 99 & 0.0 & MK 163512 \\
\hline $\mathrm{R} 2 \mathrm{~F} 4$ & Bacillus pacificus & 98 & 100 & 0.0 & MK 163513 \\
\hline $\mathrm{R} 2 \mathrm{~F} 4$ & Pseudomonas mosselii & 99 & 100 & 0.0 & MK 163514 \\
\hline R2M1 & Pseudomonas taiwanensis & 99 & 100 & 0.0 & MK 163515 \\
\hline R2M3 & Staphylococcus cohnii subsp. urealyticus & 99 & 98 & 0.0 & MK 163516 \\
\hline R2M4 & Acinetobacter soli & 98 & 100 & 0.0 & MK 163517 \\
\hline R3F1 & Pseudomonas aeruginosa & 98 & 100 & 0.0 & MK 163518 \\
\hline R3F1 & Staphylococcus gallinarum & 98 & 100 & 0.0 & MK 163519 \\
\hline R3F4 & Bacillus aerius & 98 & 100 & 0.0 & MK 163520 \\
\hline R3M3 & Staphylococcus sciuri & 98 & 99 & 0.0 & MK 163521 \\
\hline R3M4 & Micrococcus yunnanensis & 98 & 100 & 0.0 & MK 163522 \\
\hline
\end{tabular}


Table 4. The number of viable bacterial cells of an individual $P$. fuscipes female and male on selective Pseudomonas agar

\begin{tabular}{lccc}
\hline & Paederus beetles & CFU per beetle & CFU of Pseudomonas aeruginosa per beetle \\
\hline Light trap 1 & Female & $7.75 \times 10^{5} \pm 7.08 \times 10^{4}$ & $7.75 \times 10^{5} \pm 7.08 \times 10^{4}$ \\
& Male & TFTC & N/A \\
Light trap 2 & Female & TFTC & N/A \\
& Male & $2.70 \times 10^{5} \pm 5.08 \times 10^{4}$ & TFTC \\
Light trap 3 & Female & $4.00 \times 10^{6} \pm 1.45 \times 10^{6}$ & TFTC \\
& Male & $2.70 \times 10^{6} \pm 4.48 \times 10^{5}$ & N/A \\
Light trap 4 & Female & $4.85 \times 10^{5} \pm 5.06 \times 10^{4}$ & $2.58 \times 10^{5} \pm 3.85 \times 10^{4}$ \\
& Male & $4.65 \times 10^{5} \pm 2.02 \pm 10^{4}$ & $2.27 \times 10^{5} \pm 1.48 \times 10^{4}$ \\
\hline
\end{tabular}

TFTC indicates too few too count. N/A indicates not available.

Table 5. Characteristics of isolated bacteria from $P$. fuscipes beetle on selective Pseudomonas agar

\begin{tabular}{|c|c|c|c|c|c|c|c|c|c|}
\hline \multirow{2}{*}{ Isolate } & \multicolumn{8}{|c|}{ Colony Morphology } & \multirow{2}{*}{$\begin{array}{c}\text { Gram's } \\
\text { Stain }\end{array}$} \\
\hline & Pigmentation & Size & Shape & Opacity & Margin & Elevation & Viscosity & $\begin{array}{l}\text { Surface } \\
\text { texture }\end{array}$ & \\
\hline F3 & Greenish & Medium & Circular & Translucent & Entire & $\begin{array}{l}\text { Grow in } \\
\text { medium }\end{array}$ & Yes & Glistening & Rod, -ve \\
\hline F3 & Yellowish & Small & Circular & Opaque & Entire & Flat & No & Rough & Rod, -ve \\
\hline M2 & Clear white & Small & Circular & Opaque & Entire & Convex & No & Glistening & Rod, -ve \\
\hline $\mathrm{F} 4$ & Clear white & Small & Circular & Opaque & Entire & Flat & No & Glistening & Rod, -ve \\
\hline M4 & Clear white & Small & Circular & Opaque & Entire & Convex & Yes & Glistening & Rod, -ve \\
\hline M4 & $\begin{array}{l}\text { Fair white- } \\
\text { yellowish }\end{array}$ & Small & Circular & Opaque & Entire & Convex & Yes & Glistening & Rod, -ve \\
\hline
\end{tabular}

Table 6. The 16S rRNA gene sequence of isolated bacteria from $P$. fuscipes on selective Pseudomonas agar

\begin{tabular}{clcccc}
\hline Isolate & Description & $\begin{array}{c}\text { Maximum } \\
\text { Identity (\%) }\end{array}$ & $\begin{array}{c}\text { Query } \\
\text { Coverage (\%) }\end{array}$ & E value & Accession Number \\
\hline F3 & Pseudomonas aeruginosa & 98 & 95 & 0.0 & MK 163523 \\
F3 & Pseudomonas oryzihabitans & 99 & 99 & 0.0 & MK 163524 \\
M2 & Enterobacter hormaechei & 95 & 97 & 0.0 & MK 163525 \\
F4 & Stenotrophomonas maltophilia & 99 & 100 & 0.0 & MK 163526 \\
M4 & Stenotrophomonas pavanii & 98 & 100 & 963527 & 0.0 \\
M4 & Pseudomonas entomophila & 98 & 96 & MK 163528 \\
\hline
\end{tabular}

Pseudomonas species. However, our results showed that $P$. aeruginosa was the dominant species identified on the selective Pseudomonas agar which existed in five out of eight individuals sampled from all four light trap location, except for $P$. fuscipes female beetle in LT 3 where the $P$. oryzihabitans colonies were found to be slightly higher in number with $4.00 \times 10^{6} \pm 1.45 \times 10^{6} \mathrm{CFU}$ counts per beetle (Table 4). On the other hand, $P$. entomophila was identified in both female and male beetles from LT 4 but the number of colonies was too few to be counted (TFTC) as compared to $P$. aeruginosa. Interestingly, in addition to the genus Pseudomonas, Stenotrophomonas, and Enterobacter are other genera which were also cultured on Pseudomonas agar, and identified from female beetle at LT 2 and both female and male beetles at LT 4 location (Table 6).

\section{DISCUSSION}

A large diverse community of bacteria has been isolated from $P$. fuscipes beetle captured from all light trap locations with an overall of 11 genera and 20 species. Based on the colony appearance on the isolation medium, most captured beetles were shown to carry a variety of bacteria, and some were of 
medical importance such as Staphylococcus cohnii urealyticus corrig. Kloos and Wolfshohl, and $P$. aeruginosa species (Soldera et al., 2013; Wick et al., 1990).

The current study showed that the number of colony-forming units (CFU) count was found the highest in male beetles, in contrast to female beetles on the NA. Thus, it suggested that $P$. fuscipes male houses a diversity of bacterial symbionts compared to female beetles. None of the $P$. aeruginosa strains were detected in P. fuscipes male beetle cultured in nutrient agar except, from a female in LT 1 location but with a low number of $P$. aeruginosa colony. However, other Pseudomonas species such as $P$. nitritireducens, $P$. mosselii, and $P$. taiwanensis was commonly detected from $P$. fuscipes population in all light trap locations with higher number of bacterial colonies.

In contrast, once the selective Pseudomonas medium was used for the isolation of bacteria from $P$. fuscipes, $P$. aeruginosa colony was not only identified in $P$. fuscipes females (LT 1, LT 3, and LT 4), but also male beetles (LT 2, LT 4). This showed that while it was possible to isolate Pseudomonas using a standard media such as NA, the culture medium does not support the growth of $P$. aeruginosa strains from $P$. fuscipes. The use of suitable selective Pseudomonas medium is recommended in increasing the efficiency of $P$. aeruginosa detection in $P$. fuscipes beetle. The results of our study showed that the CFU counts in each female beetle on the Pseudomonas medium were generally higher compared to male beetles. This could be due to the higher frequencies of $P$. aeruginosa colonies detected in $P$. fuscipes females. A study conducted by Maleki Ravasan et al. (2018) also reported that the paederin producing bacteria was also found to be four times higher in females compared to $P$. fuscipes males. This is rational because Paederus females transmit the paederin producing bacteria to their offspring from predation by natural enemies (Kellner \& Dettner, 1995; 1996). However, our findings on $P$. aeruginosa species on each light trap location was not consistent because of the low sample size of studies.

Based on the morphological characteristics of $P$. aeruginosa, the bacterial strain was in good agreement with the general description of $P$. aeruginosa colonies on the laboratory cultures. The colonies were described as Gram-negative, rodshaped, and produce water soluble pigments which diffuse through the culture medium (Gahlout et al., 2017). It contains extracellular pigments known as pyocyanin (blue-green) and pyoverdine (yellowgreen). As stated by Gahlout et al. (2017), the colour blue in pyocyanin turns stationary phase cultures of $P$. aeruginosa into the colour green. This indicates the green coloured pigment isolated from $P$. fuscipes beetle in our study is of $P$. aeruginosa species.

Although P. nitritireducens, P. mosselii, $P$. taiwanensis, $P$. oryzihabitans, and $P$. entomophila are other Pseudomonas spp. identified among the $P$. fuscipes beetles, based on the previous study conducted by Kellner (2002) at Central European on $P$. sabeus, the endosymbiont responsible for the production of toxin paederin was found to have the closest similarity with the $P$. aeruginosa species only in the "paederin-producing" (+)-females. Interestingly, the results of the present study also revealed that $P$. aeruginosa was the dominant symbiont species detected among female beetles on the selective Pseudomonas medium. It is therefore probable that the primary symbiont bacteria found in $P$. fuscipes female is $P$. aeruginosa, since they harbor significant numbers of these microorganisms in the current study.

It is notoriously known that among the genus Pseudomonas (sensu stricto), P. aeruginosa is the only fluorescent pseudomonad pathogenic to mammals including mankind (Stanier et al., 1966). According to Brock et al. (1994), P. aeruginosa is typically opportunistic, and is an important pathogen in human infection of various organs but is not an obligate parasite. Lyczak et al. (2000) stated that the ubiquitous occurrence of $P$. aeruginosa in the environment is due to its ability to utilize a wide range of simple organic compounds as energy sources. Given the widespread occurrence of $P$. aeruginosa in soil and water, it is possible for its symbiosis with Paederus beetles as they are found normally in moist environmental conditions such as the rice field areas (Bong et al., 2015). Hence, $P$. aeruginosa might indeed be the postulated producer of paederin biosynthesis which was responsible for the numerous dermatitis outbreak cases documented worldwide (Gibbs, 2015; Uzunoğlu et al., 2016; Cáceres et al., 2017). Moreover, it is also known that $P$. aeruginosa bacteria is the most common causal agent that contributes to the pathogenesis of burn wound infection (Lyczak et al., 2000). This might explain the pain or burning sensation felt by some severe form of paederus dermatitis victims throughout the world (Ghoneim, 2013). Consequently, we can deny the possibility of other Pseudomonas species that is responsible for causing paederus dermatitis infestation to human.

According to the $16 \mathrm{~S}$ rRNA sequence, the pathogenic or potentially pathogenic bacteria isolated from both male and female beetles were discovered to be from the genus Staphylococcus and Pseudomonas species. Staphylococcus cohnii subsp. urealyticus, and Pseudomonas aeruginosa are the clinically significant strains that may cause severe infections and often life-threatening diseases to 
humans (Stanier et al., 1966; Bottone et al., 2010; Soldera et al., 2013). However, bacterial isolates from the genus Serratia, Chryseobacterium, Microbacterium, Paenibacillus, Bacillus, Acinetobacter, Micrococcus, Stenotrophomonas, and Enterobacter were also found present in $P$. fuscipes beetles. The existence of these bacteria in $P$. fuscipes might cause severe secondary bacterial infections to paederus dermatitis victims.

\section{CONCLUSION}

This investigation indicated variations among the bacterial isolates found in male and female $P$. fuscipes beetles. Pseudomonas aeruginosa, the paederin producing bacteria is not only found in females, but also in male $P$. fuscipes beetles. Since the low sample size was analyzed in this study, metagenomic study on bacterial community associated with $P$. fuscipes can be conducted to understand the mechanism of endosymbiont involved in the production of paederin in Paederus females, and also to investigate the existence of other bacterial species that can cause secondary infection to paederus dermatitis victims.

\section{ACKNOWLEDGEMENTS}

We wish to thank students of Medical Entomology Laboratory, Universiti Sains Malaysia for assistance in the field. This research was funded by Research University Grant USM (1001/PBIOLOGI/811284) and graduate financial support from The Ministry of Higher Education, Malaysia for Maryam Sufian.

\section{REFERENCES}

Bong, L.J., Neoh, K.B., Jaal, Z. \& Lee, C.Y. (2015). Paederus outbreaks in human settings: a review of current knowledge. Journal of Medical Entomology, 52(4): 517-526.

Bong, L.J., Neoh, K.B., Lee, C.Y. \& Jaal, Z. (2013). Dispersal pattern of Paederus fuscipes (coleoptera: staphylinidae: paederinae) in relation to environmental factors and the annual rice crop cycle. Environmental Entomology, 42(5): 1013-1019.

Bottone, E.J. (2010). Bacillus cereus, a volatile human pathogen. Clinical Microbiology Reviews, 23(2): 382-398.

Brock, T.D., Madigan, M.T., Martinko, J.M. \& Parker, J. (1994). Biology of Microorganisms, 7th ed. Prentice Hall, Englewood Cliffs, NJ.
Cáceres, L., Suarez, J.A., Jackman, C., Galbster, A., Miranda, R., Murgas, I., Pascale, J., Sosa, N. \& Rodriguez-Morales, A.J. (2017). Dermatitis due to Paederus colombinus: report of an epidemic outbreak of 68 cases in the Province of Darien, Panama. Cureus 9.

Claus, D. (1992). A standardized Gram staining procedure. World Journal Microbiology and Biotechnology, 8(4): 451-452.

Cressey, B.D., Paniz-Mondolfi, A.E., RodríguezMorales, A.J., Ayala, J.M. \& De Ascenção Da Silva, A.A. (2013). Dermatitis linearis: vesicating dermatosis caused by Paederus species (Coleoptera: Staphylinidae). Case Series and Review. Wilderness \& Environmental Medicine, 24(2): 124-131.

Dillon, R.J. \& Dillon, V.M. (2004). The gut bacteria of insects: nonpathogenic interactions. Annual Reviews in Entomology, 49(1): 71-92.

Gahlout, M., Prajapati, H., Chauhan, P., Patel, N. \& Solanki, D. (2017). Isolation and screening of pyocyanin producing Pseudomonas spp. from soil. International Journal of Advanced Research in Biological Sciences, 4(4): 147-152.

Ghoneim, K. S. (2013). Human dermatosis caused by vesicating beetle products (Insecta), cantharidin and paederin: An overview. World Journal of Medicine and Medical Science, 1(1): 1-26.

Gibbs, L.M. (2015). Beware of the beetle: a case report of severe vesicating dermatitis. Military Medicine, 180(12): 1293-1295.

Haddad, V., Cardoso, J.L.C., Lupi, O. \& Tyring, S.K. (2012). Tropical dermatology: venomous arthropods and human skin: Part I. Insecta. Journal of the American Academy Dermatology, 67(3): 331.

Hall, T.A. (1999). BioEdit: a user-friendly biological sequence alignment editor and analysis program for Windows 95/98/NT. In Nucleic acids symposium series 41: 95-98.

Kellner, R.L. \& Dettner, K. (1995). Allocation of pederin during lifetime of Paederus rove beetles (Coleoptera: Staphylinidae): Evidence for polymorphism of hemolymph toxin. Journal of Chemical Ecology, 21(11): 1719-1733.

Kellner, R.L. \& Dettner, K. (1996). Differential efficacy of toxic pederin in deterring potential arthropod predators of Paederus (Coleoptera: Staphylinidae) offspring. Oecologia, 107(3): 293-300.

Kellner, R.L.L. (2002). Molecular identification of an endosymbiotic bacterium associated with pederin biosynthesis in Paederus sabaeus (Coleoptera, Staphylinidae). Insect Biochemistry and Molecular Biology, 32(4): 389-395. 
Lyczak, J.B., Cannon, C.L. \& Pier, G.B. (2000). Establishment of Pseudomonas aeruginosa infection: lessons from a versatile opportunist. Microbes and Infection, 2(9): 1051-1060.

Maleki-Ravasan, N., Akhavan, N., Raz, A., Jafari, M., Zakeri, S. \& Dinparast Djadid, N. (2019). Cooccurrence of pederin-producing and Wolbachia endobacteria in Paederus fuscipes Curtis, 1840 (Coleoptera: Staphilinidae) and its evolutionary consequences. Microbiology Open, 8(7): e00777.

Maryam, S., Fadzly, N., Amirul, A.A.A. \& Zuharah, W.F. (2017b). Attraction factors for Paederus fuscipes' dispersal, a vector of paederus dermatitis towards human residential premises. Revista do Instituto de Medicina Tropical de São Paulo, 59: e4.

Maryam, S., Fadzly, N. \& Zuharah, W.F. (2017a). Abundance, distribution and dispersal time of Paederus fuscipes (Coleoptera: Staphylinidae) and its association to human settings. Tropical Biomedicine, 34(1): 224-236.

Piel, J. (2002). A polyketide synthase-peptide synthetase gene cluster from an uncultured bacterial symbiont of Paederus beetles. Proceedings of the National Academy of Sciences, 99(22): 14002-14007.
Sambrook, J. \& Russell, D.W. (2001). Molecular Cloning: A Laboratory Manual, 3rd ed. Cold Spring Harbor Laboratory Press, Cold Spring Harbor, N.Y.

Soldera, J., Nedel, W.L., Cardoso, P.R.C. \& d'Azevedo, P.A. (2013). Bacteremia due to Staphylococcus cohnii ssp. urealyticus caused by infected pressure ulcer: case report and review of the literature. Sao Paulo Medical Journal, 131(1): 59-61.

Stanier, R.Y., Palleroni, N.J. \& Doudoroff, M. (1966). The aerobic pseudomonads a taxonomic study. Microbiology, 43: 159-271.

Uzunoğlu, E., Oğuz, I.D., Kır, B. \& Akdemir, C. (2016). Clinical and epidemiological features of Paederus dermatitis among nut farm workers in Turkey. The American Journal of Tropical Medicine and Hygiene, 96(2): 16-0582.

Vorderman, A.G. (1901). Huiduitslag veroorzaakt door Paederus peregrinus Fabr. Geneeskunding Tijdschrift voor Nederlandsch-Indie, 41: 282284.

Wick, M.J., Frank, D.W., Storey, D.G. \& Iglewski, B.H. (1990). Structure, function and regulation of Pseudomonas aeruginosa exotoxin A. Annu. Rev. Microbiol. 44: 335-363. 
